\title{
慢性副鼻腔炎手術症例の高齢化とその問題点
}

\author{
山岸 益夫・中野 雄一

\section{Increase in Surgery for Chronic Sinusitis among Aged Patients and Attendant Problems}

\author{
Masuo Yamagishi and Yuichi Nakano \\ (Niigata University)
}

The number of aged patients requiring nasal surgery for chronic sinusitis has been increasing as the population ages.

A clinical study on the number of aged patients, complications and factors responsible for the increasing incidence of sinusitis was conducted on patients who underwent nasal surgery for chronic sinusitis from 1983 to 1990. Patients who underwent the operation from 1963 to 1970 served as controls.

In the control group, most patients were 10 to 30 years of age. In the study group the number of aged patients had increased markedly and the distribution of patients was more equal among the age groups. There were many associated disorders, including cardiovascular disorders, lower respiratory tract disease, endocrine disorders and psychoneurotic disease. It is suspected that drugs used to treat hypertension or psychiatric diseases may aggravate chronic sinusitis, and diabetes itself may make it worse. Among aged patients, pathological change in the nasal cavity was marked, and the mucosa showed fibrosis, which was assumed to be irreversible. Nevertheless, the prognosis was good in aged patients.

These results indicate that nasal surgery for aged patients with chronic sinusitis should be performed carefully and with a full understanding of the background factors.

Key words: chronic sinusitis, aged patients, complications, problems

はじめに

厚生省が1991年 6 月に発表した「日本の将来

人口推計」によると老年人口は今後毎年急増し, 2014 年には現在の倍の約 3,000 万人に，また総 人口に老年人口が占める割合 (高齢化率)は現在 の $12.1 \%$ から2019年には $25.0 \%$ 之倍以上に上昇 すると推定されている.このような人口構成の 変化に伴って耳鼻咽喉科領域でも年々高齢者の
受診や手術件数が増加してくるのもまた当然の こととい兄よう。

鼻科領域でも確かに年々年配者の受診が増え， その代表的疾患である慢性副鼻腔炎に沶いても 手術症例の高齢化がみられる。このような高齢 者は手術そのものに対する耐性の低下はもちろ んであるが，当然種々の合併症を持っている. しかし最近の高齢者増加の状況下では高齢であ 
るから，あるいは合併症があるからといって手 術を控えるといらわけにはいかなくなってきて いる．すでに高齢者の慢性中耳炎手術症例につ いては中野ら1)により詳しく報告されているが， 慢性副鼻腔炎においてはいまだ充分に検討され ていない。

今回我々は, 最近 8 年間に慢性副鼻腔炎の診 断にて手術を行った症例について，高齢化の度 合, 合併症の種類, 手術に伴ら種々の問題, 副 鼻腔炎に影響を与える因子などについてまとめ, さらに20年前と比較して検討を加えた.

\section{対象}

1983年から1990年の 8 年間に当科で慢性副鼻 腔炎の診断にて入院, 手術を行った症例を対象 とした，後鼻孔鼻茸，免疫不全による副鼻腔真 菌症，歯性上顎洞炎，術後性上顎洞黹胞などは 対象から除外した。またこの群の対照として20 年前の1963年から1970年までの 8 年間に当科で 慢性副鼻腔炎の診断にて手術を行った症例を集 計し，比較した。便宜上前者を最近群, 後者を 過去群とした。

なお最近は，一般に65歳以上を老年者として 扱ら場合が多いが，今回は10歳単位で比較検討 する項目が多いため, 従来のごとく60歳以上を 高齢者とした。

\section{1 . 年度別患者数}

\section{結＼cjkstart果}

年度別にみた手術症例数の全体の流れを図 1 に示したが，過去群に抢いては漸減の傾向をた どりながらも手術症例数は多かった。一方最近 群では手術症例数は少ないものの再び漸増の傾 向を示している。ささらに詳細を表 1 亿示したが, 全体の症例数は過去群が最近群の約 2.7 倍であ った。すなわち全入院患者数に占める割合は， 過去群では1963年から1965年までは10\%代であ ったが，1964年の16.7\%を最高に徐々に減少し， 1970年には $5.0 \%$ まで低下している. 一方最近 群では1983年には $1.7 \%$ と非常に少ないが，そ の後次第に増加し，最近は $7 \%$ 代で推移してい る.このうち 60 歳以上の副鼻腔炎症例の占める
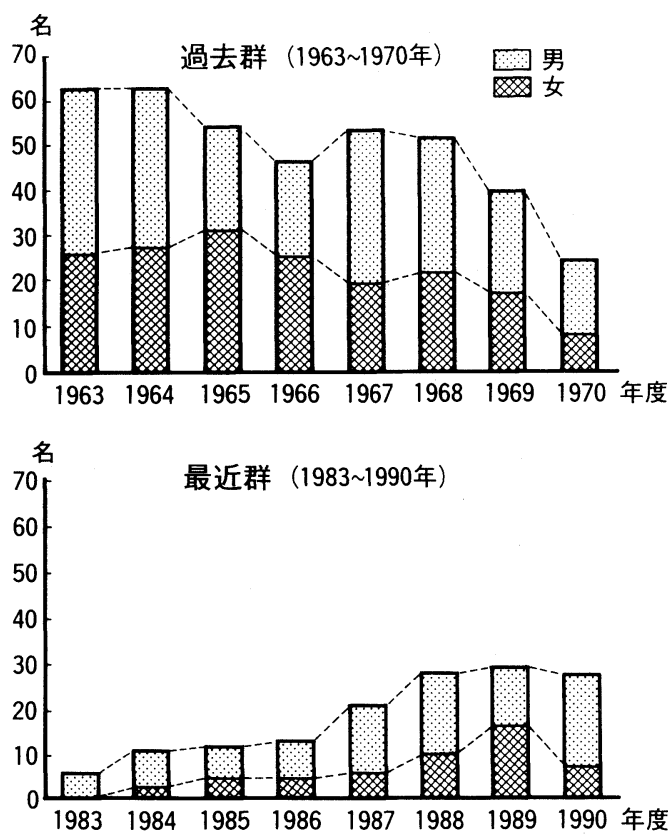

図 1 年度別にみた副鼻腔炎手術症例数の変化

表 1 年度別症例数

\begin{tabular}{|c|c|c|c|c|}
\hline 年度 & 男 & 女 & 計 & $\begin{array}{l}\text { 全入院患者に } \\
\text { 占める割合 }\end{array}$ \\
\hline 1963 & 37 & 26 & $63(0)$ & 15.4 \\
\hline 1964 & 36 & 27 & $63(0)$ & 16.7 \\
\hline 1965 & 23 & 31 & $54(0)$ & 12.5 \\
\hline 1966 & 21 & 25 & $46(0)$ & 8.8 \\
\hline 1967 & 34 & 19 & $53(0)$ & 9.5 \\
\hline 1968 & 30 & 21 & $51(0)$ & 9.3 \\
\hline 1969 & 22 & 17 & 39 (1) & 7.1 \\
\hline 1970 & 16 & 8 & $24(1)$ & 5.0 \\
\hline 計 & 219 & 174 & 393 (2) 名 & $10.4 \%$ \\
\hline 1983 & 5 & 1 & $6(1)$ & 1.7 \\
\hline 1984 & 8 & 3 & $11(1)$ & 3.1 \\
\hline 1985 & 7 & 5 & $12(3)$ & 3.4 \\
\hline 1986 & 8 & 5 & $13(5)$ & 3.9 \\
\hline 1987 & 15 & 6 & $21(2)$ & 5.8 \\
\hline 1988 & 18 & 10 & $28(5)$ & 7.4 \\
\hline 1989 & 13 & 16 & $29(7)$ & 7.6 \\
\hline 1990 & 20 & 7 & $27(4)$ & 7.0 \\
\hline 計 & 94 & 53 & 147 (28) 名 & $5.1 \%$ \\
\hline
\end{tabular}


割合は過去群ではわずか 2 名(0.5\%)であった のに対し, 最近群では28名(19.0\%) と著明に増 加していた。

\section{2 . 年齢分布}

両群間の年齢分布を図 2 および表 2 に示した. 最近群では50歳代に症例のピークがあるが，全
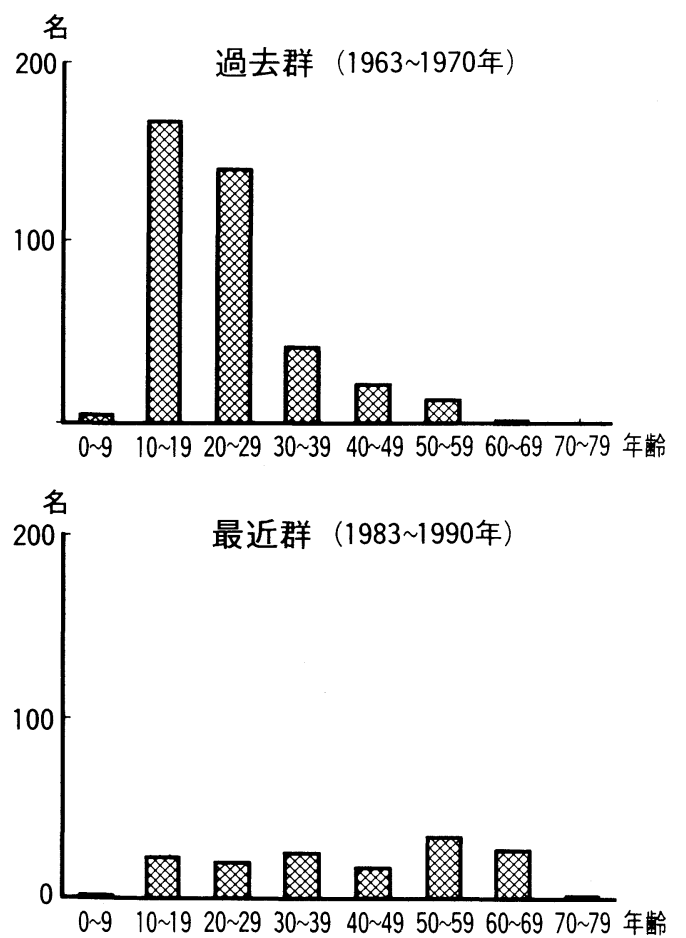

図 2 過去群および最近群の年路分布

表 2 年秢分布

\begin{tabular}{c|r|r}
\hline \hline 年 齢 & \multicolumn{1}{|c|}{ 過去群 } & \multicolumn{1}{|c}{ 最近群 } \\
\hline $0 \sim 9$ & $5(1.3)$ & $1(0.7)$ \\
$10 \sim 19$ & $167(42.5)$ & $23(15.6)$ \\
$20 \sim 29$ & $140(35.6)$ & $20(13.6)$ \\
$30 \sim 39$ & $43(10.9)$ & $25(17.0)$ \\
$40 \sim 49$ & $22(5.6)$ & $17(11.6)$ \\
$50 \sim 59$ & $14(3.6)$ & $33(22.4)$ \\
$60 \sim 69$ & $2(0.5)$ & $26(17.7)$ \\
$70 \sim 79$ & 0 & $2(1.4)$ \\
\hline 計 & 393 名(100\%) & 147 名 $(100 \%)$
\end{tabular}

体として10歳代から60歳代まで注湾各年代に均 等に分布していた。 また70歳以上の症例も 2 名 (1.4\%) 又られた。一方過去群では10歳代，20 歳代への集中が著明で，この両年齢層のみで全 体の78.1\%を占めており，60歳以上はわずか 2 名 $(0.5 \%)$ のみであった。

3 . 病型別年齢分布

慢性副鼻腔炎手術症例を病態から慢性副鼻腔 炎例(初回手術例)，慢性副鼻腔炎既手術例(再 発例)，乾酪性副鼻腔炎例(乾酪性)，アスピリ ン喘息に伴ら副鼻腔炎例 (aspirin induced asthma : AIA), 副鼻腔気管支症候群に伴ら副鼻腔 炎例 (sinobronchitis：SB)の 5 つに分類した。 このうち最近群では初回手術例拉よび再発例と も10歳代から60歳代まで各年代に注湆均等に分 布していた。これに対して過去群では初回手術 例拉よび再発例とも10歳代から20歳代に集中し ていた。ささらに最近群では乾酪性, AIA, SB などの増加が目立ち, 乾酪性副鼻腔炎は50歳以 上に，また AIA 抢よび SB は比較的若年層に 多くみられた(表 3 ).

4. 病变部位別分布

慢性副鼻腔炎症例 (初回手術例)の鼻 X線写真 所見から判定した病変部位による分類では，両 群とも両側上顎洞篩骨洞型が最も多くみられた。 しかし最近群では過去群と比較してこの型が減 少し，両側篩骨洞型が増加していた(表 4)。さ らに60歳以上の症例に限定しても，特にその傾 向に変化はなかった。また病変部位と手術法は 注ぼ一致しており，それぞれの型に応じて，上 顎洞篩骨洞根本術, 鼻内篩骨洞手術などが種々 の組合せで行われていた。なお1988年からは篩 骨洞の操作には寸べて内視鏡が用いられるよう になった。また最近群では全例全身麻酔下にて 手術が行われているが，過去群では特殊な事情 がない限り局所麻酔下にて行われており，全身 麻酔が用いられたのは小児の18例のみであった。

5. 合併症

最近群では合併症を持つ症例が多くみられた。 この内訳で主なものは高血圧, 心疾患, 脳血管 
表 3 病型別年齢分布

過去群

\begin{tabular}{c|c|c|c|c|c}
\hline \hline 年 齢 & 初回手術例 & 再発例 & 乾酪性 & AIA & SB \\
\hline $0 \sim 9$ & 5 & 0 & 0 & 0 & 0 \\
$10 \sim 19$ & 154 & 13 & 0 & 0 & 0 \\
$20 \sim 29$ & 114 & 25 & 1 & 0 & 1 \\
$30 \sim 39$ & 31 & 10 & 1 & 0 & 0 \\
$40 \sim 49$ & 17 & 5 & 0 & 0 & 0 \\
$50 \sim 59$ & 11 & 2 & 1 & 0 & 0 \\
$60 \sim 69$ & 2 & 0 & 0 & 0 & 0 \\
$70 \sim 79$ & 0 & 0 & 0 & 0 & 0 \\
\hline \multirow{2}{*}{ 計 } & 334 名 & 55 名 & 3 名 & 0 名 & 1 名 \\
\cline { 2 - 6 } & $85.0 \%$ & $14.0 \%$ & $0.8 \%$ & $0 \%$ & $0.3 \%$
\end{tabular}

最近群

\begin{tabular}{c|c|c|c|c|c}
\hline \hline 年 齢 & 初回手術例 & 再発例 & 乾酪性 & AIA & SB \\
\hline $0 \sim 9$ & 1 & 0 & 0 & 0 & 0 \\
$10 \sim 19$ & 17 & 3 & 0 & 0 & 3 \\
$20 \sim 29$ & 8 & 5 & 2 & 2 & 3 \\
$30 \sim 39$ & 18 & 4 & 0 & 3 & 0 \\
$40 \sim 49$ & 12 & 4 & 0 & 1 & 0 \\
$50 \sim 59$ & 20 & 7 & 4 & 0 & 2 \\
$60 \sim 69$ & 18 & 4 & 3 & 1 & 0 \\
$70 \sim 79$ & 1 & 0 & 1 & 0 & 0 \\
\hline & 95 名 & 27 名 & 10 名 & 7 名 & 8 名 \\
\hline 計 & $64.6 \%$ & $18.4 \%$ & $6.8 \%$ & $4.8 \%$ & $5.4 \%$
\end{tabular}

AIA : アスピリン喘息

$\mathrm{SB}$ : 副鼻腔気管支症候群

表 4 病変部位別分布 (初回手術例)

\begin{tabular}{|c|c|c|}
\hline & 過去群 & 最近群 \\
\hline 両側上顎洞管骨洞型 & $204(61.1)$ & $40(42.1)$ \\
\hline 片側上顎洞管骨洞型 & $68(20.3)$ & $24(25.3)$ \\
\hline 両側篩骨洞型 ～～～～～～～～～～ & $30(9.0)$ & $19(20.0)$ \\
\hline 片側上顎洞篩骨洞, 対側篩骨洞型 & $20(6.0)$ & $8(8.4)$ \\
\hline 片側管骨洞型 & $8(2.4)$ & $2(2.1)$ \\
\hline 片側上顎洞型 & $4(1.2)$ & $2(2.1)$ \\
\hline 計 & 334 名 $(100 \%)$ & 95 名 $(100 \%)$ \\
\hline
\end{tabular}


障害などの循環器疾患が対象例の $19.7 \%$, 気管 支喘息, 気管支拡張症, アスピリン喘息といっ た下気道疾患が $17.7 \%$, 糖尿病を含む内分泌, 代謝疾患が $6.1 \%$ な゙で，高齢者に多い疾患が 上位を占めた。 その注か精神発達遅延, てんか ん, 精神分裂病, 万つ病などの精神神経系疾患 も数例ずつみられた。 これに対し過去群では合 併症を持つ症例自体が非常に少数であった。す なわち最近群にみられるような合併疾患は汪と んどなく, 循環器系合併症例はわずか $1.5 \%$ で あった。その注か過去群には時代を反映してか 結核性病変がみられた(表 5 )。

最近群で60歳以上の症例に限定すると，64.3 \%に合併症がみられ, 疾患構造は群全体と注湆 同様であったが，合併率はいずれも高率であっ た(表 6 ).

さらに最近群で最も合併率の高い高血圧に使 用される降圧剤が慢性副鼻腔炎に影響を与兄て いる可能性があるため，これを詳細に検討した． 薬剤名の判明したものの一覧を表 7 に示したが, 非常に多種多様の薬剤が用いられていた。

\section{6. 高歯手術症例の予後}

最近群の 60 歳以上の症例の術後経過を良好 (医師の手を離れたもの), 軽快(多少症状があ るものの数力月に 1 回の経過観察で良いもの), 不良(ポリープ, 膿性鼻汁の再発) の 3 段階分類 で判定すると，良好持よび軽快が $92.9 \%$ であっ た(表 8 ).

表 660 歳以上の症例の合併症頻度 (最近群)

\begin{tabular}{|c|c|c|c|}
\hline 合併症 & 無 & 10名 & $(35.7 \%)$ \\
\hline \multirow[t]{7}{*}{ 合併症 } & 有 & 18 & $(64.3)$ \\
\hline & 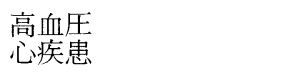 & $\left.\begin{array}{l}7 \\
2\end{array}\right] 9$ & $(32.1)$ \\
\hline & $\begin{array}{l}\text { 気管支喘息 } \\
\text { アスピリ喘息 }\end{array}$ & $\left.\begin{array}{l}3 \\
1\end{array}\right] 4$ & $(14.3)$ \\
\hline & 糖尿病, 他の代謝疾患 & 2 & $(7.1)$ \\
\hline & らつ病 & 2 & $(7.1)$ \\
\hline & 肝, 消化器疾患 & 3 & $(10.7)$ \\
\hline & 神経変性疾患 & （重複あ & $(7.1)$ \\
\hline
\end{tabular}

表 5 合併症一覧

\begin{tabular}{|c|c|c|c|}
\hline & 過 去 群 & 最 & 近 群 \\
\hline $\begin{array}{l}\text { 高血王 } \\
\text { 蒺患 } \\
\text { 脳血管障害 }\end{array}$ & $\left.\begin{array}{l}4 \\
2 \\
0\end{array}\right] 6(1.5)$ & $\left.\begin{array}{r}19 \\
7 \\
3\end{array}\right]$ & $29(19.7)$ \\
\hline 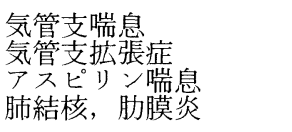 & $\left.\begin{array}{l}2 \\
1 \\
0 \\
3\end{array}\right] 6 \quad(1.5)$ & $\left.\begin{array}{c}11 \\
8 \\
7 \\
0\end{array}\right]$ & $26(17.7)$ \\
\hline $\begin{array}{l}\text { 糖尿病 } \\
\text { 他の内分泌, 代謝疾患 }\end{array}$ & 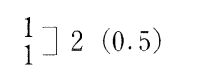 & $\left.\begin{array}{l}7 \\
2\end{array}\right]$ & $9(6.1)$ \\
\hline $\begin{array}{l}\text { 精神発達遅延 } \\
\text { 乙ん汃 } \\
\text { 精神分裂病 } \\
5 \text { 病 } \\
\text { 自律神経失調症 }\end{array}$ & $\left.\begin{array}{l}0 \\
0 \\
2 \\
0 \\
3\end{array}\right] 5(1.3)$ & $\left.\begin{array}{l}4 \\
3 \\
2 \\
2 \\
0\end{array}\right]$ & $11(7.5)$ \\
\hline 肝, 消化器疾患 & $(0.8)$ & 3 & $(2.0)$ \\
\hline 神経変性疾患 & 0 & 2 & $(1.4)$ \\
\hline 慢性腎炎 & $(0.3)$ & 0 & \\
\hline 計（重複あり） & 23名 $\quad(5.9 \%)$ & 80 名 & $(54.4 \%$ \\
\hline
\end{tabular}


表 7 高血圧症合併患者使用薬剤一覧

1. 利尿剂

1）カリウム排泄性利尿剂

Furosemide

Trichlormethiazide

2 ) カリウム保持性利尿剂

Triamterene

2. 交感神経抑制剂

1 ）中枢性交感神経抑制剂

Clonidine

Guanabenz

2 ) 末梢性交感神経抑制剤

Reserpine

Rescinnamine

3 ) 交感神経受容体遮断剂

a ) $\alpha$ 遮断剂

Prazon

Bunazosin

b ) $\alpha$ 遮断作用をもつ $\beta$ 遮断剂

Labetalol

c ) $\beta$ 遮断剂

Atenolol

Metoprolol

3 . 血管拡張剤

1 ）ヒドララジンおよび類似血管拡張剂

Hydralazine

Ecarazine

2) カルシウム拮抗剤

Nifedipine

3 ) 変換酵素阻害剂

Captopril

Enalapril

4. その他

Kallidinogenase

$\underline{\text { Reserpine }+ \text { Hydralazine }}$

+ Hydrochlorthiazine 合剂

※重複あり

下線は副作用として鼻症状の記載のあ

るもの

表 860 歳以上の症例の術後経過(最近群)

\begin{tabular}{c|r}
\hline \hline 術後経過 & 症 例 数 \\
\hline 良 好 & $23(82.2)$ \\
軽 快 & $3(10.7)$ \\
不 良 & $2(7.1)$ \\
\hline 計 & 28 名 (100\%)
\end{tabular}

表 9 鼻腔内所見からみた副鼻腔炎の重症度分類

1 、鼻腔内に鼻茸は認められないが，粘性あるい は膿性の鼻汁がみられる。

2. 中鼻道に小鼻茸が存在し, 中鼻甲介あるいは 下鼻甲介粘膜の腫脹がみられる.

3. 中鼻道にかなり大さな鼻茸が認められる.

4. 鼻腔全体を閉塞するような大きな鼻茸あるい は分葉状の多数の鼻茸が認められ, 鼻呼吸が まったくできない。

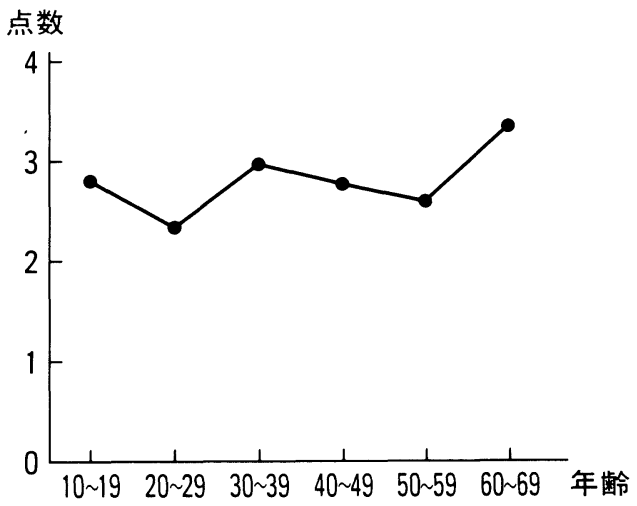

図 3 鼻内所見からみた副鼻腔炎重症度（最近群）

表10 病理組織型による分類(最近群)

\begin{tabular}{c|c|c|c}
\hline \hline 年 齢 & 浮腫型 & 細胞浸潤型 & 線維型 \\
\hline $10 \sim 19$ & 19 & 9 & 1 \\
$20 \sim 29$ & 12 & 4 & 4 \\
$30 \sim 39$ & 12 & 4 & 1 \\
$40 \sim 49$ & 3 & 4 & 0 \\
$50 \sim 59$ & 7 & 16 & 6 \\
$60 \sim 69$ & 5 & 8 & 13 \\
$70 \sim 79$ & 0 & 1 & 0 \\
\hline 計 & 58 洞 & 46 洞 & 25 洞
\end{tabular}


7. 高齢者の鼻腔内所見および病理組織所見 の特徵

最近群に扣ける副鼻腔炎の程度を鼻腔内所見 および上顎洞粘膜病理組織所見から分類した。 鼻腔内所見は鼻茸の有無を中心にして表 9 の分 類にしたがい $1 \sim 4$ までに分類し，それぞれに $1 \sim 4$ 点を対応させ，計算した平均点で病変の 程度を表現した。この平均点は10歳から50歳代 は 2 点代であるのに対して 60 歳代では 3.2 点で あり，また 60 歳未満では平均 2.7 点であるのに 対し60歳以上では3.2点で，高齢者では鼻腔内 病变が高度であった（図 3 )。上顎洞粘膜の組織 像を観察することができた94症例，129洞の粘 膜組織型をその中心病変の種類により浮腫型, 細胞浸潤型，線維型として分類すると，10歳か ら30歳代では浮腫型が，50歳代では細胞浸潤型 が，60歳代では線維型が多くみられた(表10).

\section{考察}

人口構成の高齢化に伴って高齢者の受診が増 加すると，当然高㛔者の手術症例も増加する. 当科でも1984年ごろまでは60歳以上の副鼻腔炎 手術症例は 1 年に 1 例程度であったが，1985年 頃から徐々に増加し始めている。これを20年前 と比較すると 30 歳以上の各年齢層での症例がい ずれも増加し，高齢化とともに各年齢層が均等 化してきたことがわかる．これは受診副鼻腔炎 罹患患者全体にもいえることで，和田）㧊よび 平杉3) は慢性副鼻腔炎の受診者数の全受診者中 に占める割合は年々減少していくが，年齢構成 は若年型中心から次第に全年齢層に分布するよ らになってきたと報告している。

高齢者の手術に際しては特有の問題点がいく つかある．まず第一は手術適応の問題である. これは高齢者の副鼻腔炎の病態をよく知った上 で決定されなければならない。これまでの報告 によると慢性副鼻腔炎症例の上顎洞粘膜病理組 織型は若年者で浮腫型が，青壮年で細胞浸潤型 が，高齢者では線維型が多い傾向が知られてい る4)5)。すなわち八尾6)の詳細な報告にみられる ように，加齢に伴って結合組織が増加寸ると同
時に，逆に腺組織密度が減少し，線維化が進む といった不可逆性変化が生じてくることが考光 られている．今回我々の検討でも上顎洞粘膜病 理組織所見はこれらの報告と一致していた。さ らに鼻腔内所見では鼻茸形成のみられるものが 増加し，病変も高度になっていた。このような 観点から現在我々は保存的療法によっても鼻症 状および鼻 $\mathrm{X}$ 線写真所見が改善せず，かつ鼻腔 内に鼻茸の形成のある症例には原則として高齢 者でも手術をすすめている。一方間島ら7)は60 歳以上の慢性副鼻腔炎患者について検討を加兄 60 歳以上の患者でも保存的療法，特に上顎洞洗 浄療法を行うことにより良好な結果が得られた と報告している。このように高齢者に対しては できるだけ保存的に治療することも一つの方法 である。しかし，一方では高齢者も最近は快適 な日常生活を送るため不快な鼻症状の改善を望 及, 手術治療に対する要望も強く, 高齢だから 合併症があるからといら理由の久で慢性副鼻腔 炎の手術を控えることは実情に合わなくなって きた。

その合併症であるが，結果の項で述べたよう 飞循環器疾患, 下気道疾患, 内分泌代謝疾患, 精神神経疾患など種々の疾患が高齢者には高率 に合併して拉り，これらの術前，術後管理には 他科との密接な協力が必要であると同時に，耳 鼻咽喉科医にも合併症に対する基礎知識が要求 されることを示している。

第二は麻酔法の問題である．以前は副鼻腔炎 手術の汪とんどが局所麻酔下に行われていたが， 高齢者に対しては全身管理が容易な全身麻酔法 が適切であると思われる．特に循環器系に問題 のある患者は血圧のコントロールが必要なため 全身麻酔法を使用せざるを得ない。

さらにこれらの疾患の中には疾患そのものが， あるいは治療薬として使われる薬剂が慢性副鼻 腔炎の増悪因子となりらるものがある，その一 つに最近の副鼻腔炎手術症例に高率に合併して いる高血圧があり，注とんどの患者が例外なく 降圧剂を服用している。この薬剤が鼻閉を生ず 
ることはよく知られており, 慢性副鼻腔炎にも 何らかの悪影響を与えている可能性がある。中 でもとくに鼻症状を強く生ずるのは交感神経抑 制剂系执よび血管拡張剤系中のヒドララジン類 薬剂である。これらは鼻粘膜の血管拡張作用を もち粘膜腫脹を起こすため，上㴿洞自然口の閉 鎖, 鼻茸の増悪などが生じ, 副鼻腔炎が悪化す る可能性が考兄られる。したがって副鼻腔炎を 持っている患者に対しては，鼻症状を生じにく い利尿剂系，あるいは血管拡張剂系のなかでも カルシウム拮抗剤類あるいは変換酵素阻害剤類 などの降圧剤を中心に投与するといった配慮も 必要と思われる。

汪かには精神分裂病やらつ病に使用される抗 精神病薬あるいは抗らつ阂がある。これらも鼻 閉，鼻内乾燥，口渴を起こすことが知られてい る. 今回最近群のなかにもかなり長期間使用さ れていた症例があり, 慢性副鼻腔炎の増悪因子 になりらると考えられた。

その活力糖尿病も細菌に対する易感染性, 線 毛運動機能低下などにより副鼻腔炎を増悪させ る因子になりらる8).

このよらに種々の副鼻腔炎増悪因子が高齢者 では複雑に絡久合っている可能性があり，この ことは50歳代，60歳代の患者が小児期より鼻症 状があったにも関わらず放置していて，高龄に なって手術を行ったのではなく，比較的高齢に なってから発症あるいは症状が増悪して受診し ていることからも推定できる.

最後に高齢者副鼻腔炎の予後に関寸る問題も 検討されなければならない。これまで高齢者に 対する鼻手術の術後経過について詳細な報告が ないため，予後は不明な点が多かった。しかし 今回の観察では手術症例の $92.9 \%$ が良好な経過 をたどって扣り，高齢者の手術症例の予後は良 好といら結果が得られた。このことは高齿者と いえども副鼻腔炎手術の適応例には積極的に対 応する必要性のあることを示唆するものである. しかしその場合高㱓者それぞれが持つ背景を充
分に把握して手術を行らことが大切である.

\section{まとめ}

最近 8 年間の慢性副鼻腔炎手術症例の高齢化 傾向を調べるために，20年前の群と比較して検 討した。 その結果, 最近群では高齢者が多いこ 之, 合併症を持つ症例が多いこと, 合併症は高 血圧が中心であることなどが判明した．さらに これらの患者の湟とんどが降圧剤を服用してい たことから，この薬剤が副鼻腔炎増悪因子であ る可能性も示唆された。 また高龄者といえども 全身管理を含めた手術適応例の手術成績, 経過 は良好なことが判明した。

\section{参考文献}

1）中野雄一, 黒田京子, 柳澤晴子, 他：60才以上 の慢性中耳炎と鼓室形成術. 耳展 $26: 357 \sim 366$, 1983.

2）和田健二：慢性副鼻腔炎の疫学的背景. 鼻副鼻 腔 $19: 27 \sim 28,1980$.

3）平杉嘉昭：外来患者統計と学校検診の立場上り. 鼻副鼻腔 $19: 28 \sim 29,1980$.

4）古賀慶次郎，水谷雅俊 : 高齢者慢性副鼻腔炎の 病理組織学的研究. 耳喉 32 : 815 821, 1960.

5) 武井 隆 : 慢性副鼻腔炎上顎洞粘膜の病理組織 学的研究一特に年㱓的にみた病変の差異につ いて.耳鼻臨床 13 補 $2: 229 \sim 251,1967$.

6）八尾和雄 : 老人と副鼻腔炎. 耳鼻咽喉科・頭頸 部外科 MOOK (野村恭也, 本庄 整編). 258 ～264頁, 金原出版, 東京, 1989 .

7）間島雄一, 坂倉康夫, 斎田 哲, 他 : 高路慢性 副鼻腔炎患者に対する治療とその効果. 耳展 59 : 973 976, 1987.

8) Jackson RM and Rice DH : Acute bacterial sinusitis and diabetes melitus. Arch Otolaryngol Head Neck Surg $97: 469 \sim 473$, 1987.

$$
\left(\begin{array}{l}
\text { 原稿受付: 平成 } 3 \text { 年 } 12 \text { 月 } 9 \text { 日 } \\
\text { 原稿採択 : 平成 } 4 \text { 年 } 1 \text { 月 } 8 \text { 日 } \\
\text { 別刷請求先 : 山岸益夫 } \\
\text { 个951 新潟市旭町通一番町 } \\
\text { 新潟大学医学部耳鼻咽喉科学教室 }
\end{array}\right)
$$

